\title{
Diplofuranones A and B, two further new 4-monosubstituted 2(3H)-dihydrofuranones produced by Diplodia corticola, a fungus pathogen of cork oak
}

\author{
Antonio Evidente, ${ }^{a, *}$ Anna Andolfi, ${ }^{\text {a }}$ Michele Fiore, ${ }^{\text {a Emanuela Spanu, }}$ \\ Antonio Franceschini, ${ }^{b}$ and Lucia Maddau ${ }^{b}$ \\ a Dipartimento di Scienze del Suolo, della Pianta, dell'Ambiente e delle Produzioni Animali, \\ Università di Napoli Federico II, 80055 Portici, Italy \\ ${ }^{b}$ Dipartimento di Protezione delle Piante, Università di Sassari, 07100 Sassari, Italy \\ E-mail: evidente@unina.it
}

\section{Designated for the Commemorative issue in honor of Prof. Atta-ur-Rahman on his $65^{\text {th }}$ anniversary}

\begin{abstract}
Two new 4-monosubstituted 2(3H)-dihydrofuranones, named diplofuranones $\mathrm{A}$ and $\mathrm{B}$, were isolated from liquid cultures of Diplodia corticola, a plant pathogenic fungus causing a canker disease of cork oak (Quercus suber L.). The same fungus also produces several metabolites such as the diplopyrone, the $(3 S, 4 R)$-trans- and the $(3 R, 4 R)$-cis-4-hydroxymellein, the sapinofuranone $\mathrm{B}$ and its $(S, S)$-enantiomer, the well known sphaeropsidins $\mathrm{A}-\mathrm{C}$, and the diplobifuranylones $\mathrm{A}$ and $\mathrm{B}$. The diplofuranones $\mathrm{A}$ and $\mathrm{B}$ were characterised, using spectroscopic (essentially NMR and MS techniques) methods, as the 4-[(1E,3E)-5-hydroxyhexadienyl]butan-4-olide and its corresponding 3,4-dihydro side chain derivative. The stereochemistry of the stereogenic secondary hydroxylated carbon of the side chain of diplofuranone A was determined by application of Mosher's method and proved to be $R$. Diplofuranone A tested at $0.2 \mathrm{mg} \mathrm{mL}^{-1}$ on non-host plant did not show phytotoxic activity.
\end{abstract}

Keywords: Cork oak, Quercus suber L., canker disease, Diplodia corticola, phytotoxic metabolites

\section{Introduction}

Diplodia corticola, anamorph of Botryosphaeria corticola Phillips Alves et Luque, is an endophytic fungus widespread in Sardinian oak forests, and considered one of the main causes of cork oak (Quercus suber L.) decline. ${ }^{1}$ The fungus can affect plants of different age, inducing 
symptoms which include dieback, cankers and vascular necrosis. When inoculated on stems of young cork oak plants, $D$. corticola induced a slight collapse and dark brown discoloration of the cortical tissues around the inoculation site, a sudden wilting of the plant above it and subsequently a sprouting of secondary shoots below it. ${ }^{2}$ These symptoms suggested that the fungus produced phytotoxic metabolites, as also observed for isolates of $D$. mutila from cypress and other oak species. ${ }^{3}$ The main toxin, a new monosubstituted tetrahydropyranpyran-2-one, named diplopyrone, was isolated and chemically and biologically characterized from the culture filtrates of $D$. corticola. ${ }^{4}$ Successively, the no empirical assignment of its absolute configuration has been approached by two different methods. ${ }^{5}$ Recently, two 5 '-monosubstituted tetrahydro$2 H$-bifuranyl-5-ones, named diplobifuranylones $\mathrm{A}$ and $\mathrm{B}$, together with the $(3 S, 4 R)$-trans- and the $(3 R, 4 R)$-cis-4-hydroxymellein, the sapinofuranone $\mathrm{B}$ and its $(S, S)$-enantiomer and the well known sphaeropsidins A-C were reported as metabolites from the same fungus. ${ }^{6}$ It is important underlined that sapinofuranone $\mathrm{B}$ and its $(S, S)$-enantiomer were obtained from the same fungal organic extract but in two independent experiments.

This paper describes the isolation and the chemical characterization of other two metabolites produced by $D$. corticola, which being structurally closed to sapinofuranones A and B (5 and $\mathbf{6}$, Figure 1), are named diplofuranones A and B (1 and 2, Figure 1).

\section{Results and Discussion}

The organic extract obtained from culture filtrates of $D$. corticola was purified as described in the experimental section. From the most polar fraction of the second column were isolated the diplopyrone $^{4}$ and the diplobifuranylones $\mathrm{A}$ and $\mathrm{B}$ as recently described. ${ }^{6}$. From the less polar fractions of the same column were isolated the sphaeropsidins $\mathrm{A}-\mathrm{C}^{3}$ and the sapinofuranone $\mathrm{B}$ already described together to sapinofuranone $\mathrm{A}^{7}$ as phytotoxic metabolites produced by Sphaeropsis sapinea f.s. cupressi and S. sapinea phytopathogenic fungi on cypress (Cupressus sempervirens L.) and others conifers, respectively, and $(3 S, 4 R)$-trans- and $(3 R, 4 R)$-cishydroxymellein. $^{8-10}$

The purification of the residue of fraction 5 of the initial column by TLC steps (see Experimental Section) yielded two metabolites as homogeneous oils resistant to crystallization, named diplofuranones A and B (1 and 2, 10 and $1.8 \mathrm{mg}, \mathbf{1}$ and $0.2 \mathrm{mg} / \mathrm{l})$.

Diplofuranone A, assayed at $0.2 \mathrm{mg} / 1$ on non-host tomato plant, did not show phytotoxic activity. The phytotoxicity of diplofuranone B was not assayed due to the lacking of sufficient amount of this fungal metabolite. This inactivity did not surprise as $\mathbf{1}$, in respect to the phytotoxic sapinofuranones A and B (5 and 6), showed a markedly modification of the 1-hydro2,4-hexadienyl side chain at C-4, which thus showed its importance into impart the phytotoxicity. 


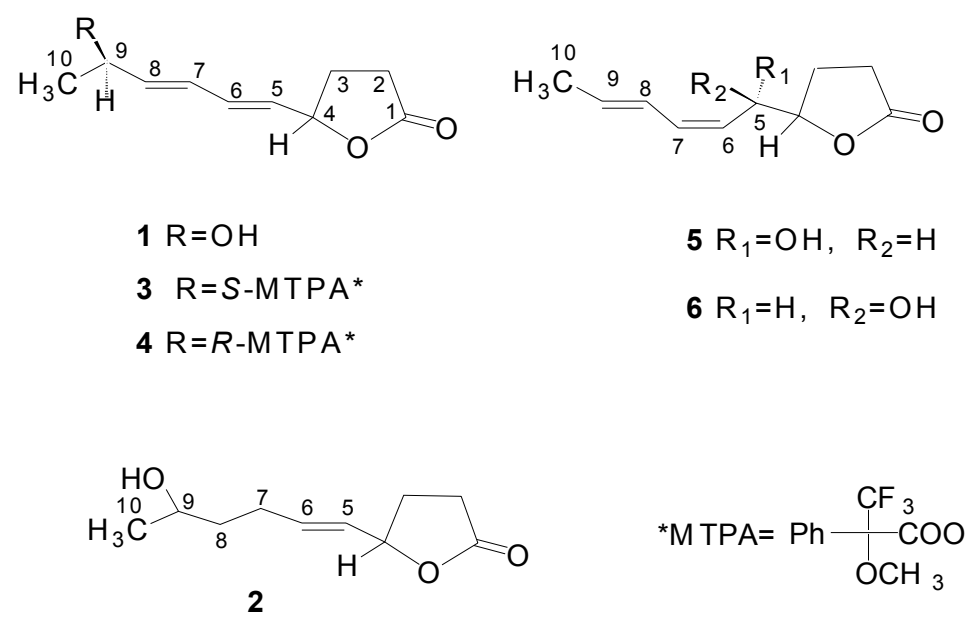

Figure 1. Structures of diplofuranones A and B (1 and 2), the MTPA esters of diplofuranone A (3 and 4), and sapinofuranones A and B (5 and 6).

Diplofuranone A (1, Figure 1) has a molecular formula of $\mathrm{C}_{10} \mathrm{H}_{14} \mathrm{O}_{3}$, corresponding to four degrees of unsaturations, as deduced from the molecular weight of 182.0954 , measured by HREIMS spectrometry. Absorption bands typical of $\gamma$-lactone carbonyl groups and hydroxy groups were observed in the IR spectrum, ${ }^{11}$ while the UV spectra showed the absorption maximum of a dienyl residue at $230 \mathrm{~nm} .^{12}$

Preliminary ${ }^{1} \mathrm{H}$ - and ${ }^{13} \mathrm{C}-\mathrm{NMR}$ spectra, compared to those of sapinofuranone $\mathrm{A}$ and $\mathrm{B},{ }^{7}$ showed a similar pattern for the $\gamma$-lactone residue while those of the side chain at C-4 appeared strongly modified.

In particular, the ${ }^{1} \mathrm{H}-\mathrm{NMR}$ spectrum (Table 1) of diplofuranone A showed the multiplet of the protons of the two methylene groups $\left(\mathrm{CH}_{2}-2\right.$ and $\left.\mathrm{CH}_{2}-3\right)$ and the quartet $(J=6.6 \mathrm{~Hz})$ of the methyne (HC-4) group positioned, respectively, in $\alpha, \beta$ and $\gamma$ in respect of the $\gamma$-lactone group, at the typical chemical shift values of $\delta 2.41$ and 2.00, 2.55 and 2.00, and 4.98, respectively. ${ }^{12}$ The latter proton (H-4) coupled in the COSY spectrum ${ }^{13}$ with the protons of $\mathrm{CH}_{2}-3$ and with the olefinic proton of the dienyl system present in the side chain attached at C-4. This latter (H-5) appeared as a double doublet $(J=14.7$ and $J=6.6 \mathrm{~Hz})$ at $\delta 5.65$ as well as the other three dienyl protons (H-6, H-7 and H-8) resonating at $\delta 6.27(J=14.7$ and $J=10.6 \mathrm{~Hz}), 6.25(J=14.9$ and $J=$ $10.6 \mathrm{~Hz})$ and $5.83(J=14.9$ and $J=6.1 \mathrm{~Hz})$ and as expected coupling themselves in the COSY spectrum. In the same spectrum the olefinic proton at $\delta 5.83$ also coupled with the proton of a secondary hydroxylated carbon $(\mathrm{CH}-9)$ appearing as a double quartet $(J=6.1$ and $J=6.4 \mathrm{~Hz})$ at $\delta$ 4.37 being also coupled with the terminal methyl group observed at $\delta 1.30$ as a doublet $(J=6.4$ $\mathrm{Hz}$ ). In the ${ }^{13} \mathrm{C}$-NMR spectrum (Table 1) the carbons of the $\gamma$-lactone ring recorded at $\delta 176.8$, 28.5, 28.7 and 80.3 (C-1, C-2, C-3 and C-4) were in perfect agreement with the values recorded for sapinofuranone $\mathrm{A}$ and $\mathrm{B}^{7}$ and literature, ${ }^{14}$ while the carbons of the side chain, in particular those of the dienyl system, were assigned on the basis of the couplings observed in HSQC spectrum. ${ }^{14}$ Therefore, the doublets of olefinic carbons observed at $\delta 139.7,132.2,129.9$ and 
127.6 were attributed to $\mathrm{C}-8, \mathrm{C}-6, \mathrm{C}-5$ and $\mathrm{C}-7$, respectively, as well as the doublet and the quartet recorded at $\delta 68.2$ and 23.2 were assigned to C-9 and C-10, respectively. ${ }^{14}$

On this basis diplofuranone $\mathrm{A}$ (1) can be formulated as the 4-[(1E,3E)-5hydroxyhexadienyl]butan-4-olide. This structure was supported by the ${ }^{1} \mathrm{H},{ }^{13} \mathrm{C}$ long-range correlations recorded for $\mathbf{1}$ in the HMBC spectrum (Table 1), ${ }^{13}$ and by data of its MS spectra. The HREIMS spectrum, in addition to the molecular ion [M] ${ }^{+}$at $m / z 182.0954$, showed the peaks generated from fragmentation typical of the $\gamma$-lactone and $\alpha$-alkadienoyl substituted furan ring. ${ }^{12,15}$ In fact, the molecular ion by successive loss of $\mathrm{H}_{2} \mathrm{O}$ and Me generated the ion at $\mathrm{m} / \mathrm{z}$ 164 and 149, respectively.

Table 1. ${ }^{1} \mathrm{H}$ - and ${ }^{13} \mathrm{C}-\mathrm{NMR}$ data of diplofuranones A and B (1 and 2). Chemical shifts reported as $\delta$ values from $\mathrm{TMS}^{\mathrm{a}}$

\begin{tabular}{|c|c|c|c|c|c|c|}
\hline \multicolumn{4}{|c|}{1} & \multicolumn{3}{|c|}{2} \\
\hline $\begin{array}{l}\text { Positi- } \\
\text { on }\end{array}$ & $\mathrm{C}^{\mathrm{b}}$ & $\mathrm{H}$ & $\mathrm{HMBC}$ & $\mathrm{C}^{\mathrm{b}}$ & $\mathrm{H}$ & HMBC \\
\hline 1 & 176.8; s & & $2.55,2.41$ & 177.2; s & & $2.52,2.39$ \\
\hline 2 & $28.5 ; \mathrm{t}$ & $\begin{array}{l}2.41 ; \mathrm{m} \\
2.00 ; \mathrm{m}\end{array}$ & & $29.7 ; \mathrm{t}$ & $\begin{array}{l}2.39 ; \mathrm{m} \\
1.98 ; \mathrm{m}\end{array}$ & $2.52,1.98$ \\
\hline 3 & $28.7 ; \mathrm{t}$ & $\begin{array}{l}2.55 ; \mathrm{m} \\
2.00 ; \mathrm{m}\end{array}$ & $5.65,4.98,2.41$ & $28.0 ; \mathrm{t}$ & $\begin{array}{l}2.52 ; \mathrm{m} \\
1.98 ; \mathrm{m}\end{array}$ & 5.53 \\
\hline 4 & $80.3 ; \mathrm{d}$ & 4.98; q (6.6) & $\begin{array}{c}6.27,5.65,2.51 \\
2.41,2.00\end{array}$ & $80.9 ; \mathrm{d}$ & $4.91 ; \mathrm{q}(6.8)$ & 5.83 \\
\hline 5 & 129.9; d & $\begin{array}{c}5.65 ; \mathrm{dd}(14.7, \\
6.6)\end{array}$ & $2.41,2.00$ & $130.7 ; \mathrm{d}$ & $\begin{array}{c}5.53 ; \text { dd (15.1, } \\
6.8)\end{array}$ & $2.52,1.98$ \\
\hline 6 & $132.2 ; \mathrm{d}$ & $\begin{array}{c}6.27 ; \mathrm{dd}(14.7 \\
10.6)\end{array}$ & $5.83,4.98$ & $128.0 ; \mathrm{d}$ & $\begin{array}{c}5.83 ; \mathrm{dt}(15.1, \\
6.8)\end{array}$ & 2.52 \\
\hline 7 & 127.6; d & $\begin{array}{c}6.25 ; \text { dd }(14.9, \\
10.6)\end{array}$ & 5.65 & $27.9 ; \mathrm{t}$ & $2.22 ; \mathrm{m}(2 \mathrm{H})$ & 5.53 \\
\hline 8 & 139.7; d & $\begin{array}{c}5.83 ; \text { dd }(14.9, \\
6.1)\end{array}$ & 1.30 & $31.6 ; \mathrm{t}$ & $2.22 ; \mathrm{m}(2 \mathrm{H})$ & 1.21 \\
\hline 9 & $68.2 ; \mathrm{d}$ & $4.37 ; \mathrm{dq}(6.4,6.1)$ & $6.25,5.83,1.30$ & $67.8 ; \mathrm{d}$ & $\begin{array}{c}3.82 ; \operatorname{sex}(6.3 \\
6.0)\end{array}$ & \\
\hline 10 & $23.2 ; \mathrm{q}$ & $1.30 ; \mathrm{d}(3 \mathrm{H}, 6.4)$ & 5.83 & $23.5 ; \mathrm{q}$ & $\begin{array}{c}1.21 ; \mathrm{d}(3 \mathrm{H}, \\
6.0)\end{array}$ & \\
\hline
\end{tabular}

${ }^{\mathrm{a}} 2 \mathrm{D}{ }^{1} \mathrm{H},{ }^{1} \mathrm{H}(\mathrm{COSY})$ and $2 \mathrm{D}{ }^{13} \mathrm{C},{ }^{1} \mathrm{H}$ (HSQC) NMR experiments delineated the correlations of all protons and the corresponding carbons

${ }^{\mathrm{b}}$ Multiplicities determined by DEPT spectroscopy 
Alternatively the molecular ion $[\mathrm{M}]^{+}$, by loss of the alkadienoyl side chain generated the ion at $m / z$ 85. In addition, the ions yielded by the side chain and that generated from it by $\mathrm{H}_{2} \mathrm{O}$ loss were recorded at $m / z 97$ and 79, respectively. The ESIMS(+) spectrum showed the potassium $[\mathrm{M}+\mathrm{K}]^{+}$and the sodium $[\mathrm{M}+\mathrm{Na}]^{+}$clusters at $\mathrm{m} / \mathrm{z} 221$ and 205 , respectively.

Diplofuranone B (2, Figure 1) has a molecular formula of $\mathrm{C}_{10} \mathrm{H}_{16} \mathrm{O}_{3}$ as deduced its HREIMS spectrum and spectroscopic properties (IR, NMR and MS spectra) similar to those described for 1. Therefore, it differed in respect to $\mathbf{1}$ for the lack of unsaturation which was localized in the side chain. In fact, in the UV spectrum of 2 was absent the typical absorption maximum of a dienyl system observed in the same spectrum of $\mathbf{1}$. Therefore, $\mathbf{2}$ showed a different side chain in respect to 1 as suggested also observing its ${ }^{1} \mathrm{H}$ - and ${ }^{13} \mathrm{C}$-NMR spectra (Table 1). In fact, these latter differed from those of $\mathbf{1}$ only for the signal system of the side chain residue while those of the $\gamma$-lactone ring remained substantially unaltered. In particular, the ${ }^{1} \mathrm{H}$ NMR spectrum showed the presence of only two coupled olefinic protons (H-6 and H-5) resonating at $\delta 5.83$ and 5.53 as a double triplet $(J=15.1$ and $J=6.8 \mathrm{~Hz})$ and a double doublet $(J=15.1$ and $J=6.8 \mathrm{~Hz})$, respectively. The latter proton (H-5) coupled with the proton of the methyne group (HC-4) of the $\gamma$-lactone ring which as in $\mathbf{1}$ appeared as a quartet $(J=6.8 \mathrm{~Hz})$ at a very similar chemical shift value of $\delta$ 4.91. The other olefinic proton (H-6) coupled with the protons of the adjacent methylene group $\left(\mathrm{H}_{2} \mathrm{C}-7\right)$ resonating as a multiplet at $\delta 2.22$ and these in turn with the protons of another methylene group $\left(\mathrm{CH}_{2}-8\right)$ always appearing as multiplet and at the same chemical shift value. These latter protons $\left(\mathrm{H}_{2} \mathrm{C}-8\right)$, in turn, coupled with a sextet of a secondary hydroxylated carbon (HC-9), which, as expected, appeared upfield shifted $(\Delta \delta 0.55)$ in respect to 1 at $\delta 3.82$, being also coupled with the terminal methyl group (Me-10) resonating as the doublet $(J=6.0 \mathrm{~Hz})$ at $\delta 1.21$.

The ${ }^{13} \mathrm{C}$-NMR spectrum (Table 1) showed signals very similar to those of $\mathbf{1}$ for the carbons of the $\gamma$-lactone ring but differed for those of the side chain. The olefinic carbons resonated at $\delta$ 130.7 and 128.0 (C-5 and C.6), while the carbons of the two new methylene groups, the secondary hydroxylated carbon and the terminal methyl group were recorded at expected chemical shifts values of $\delta 27.9,31.6,67.8$ and 23.5 (C-7, C-8, C-9 and C-10). ${ }^{14}$

On the basis of these results diplofuranone $\mathrm{B}$ differed from $\mathbf{1}$ for the side chain and in particular for the lacking of the double bond between $\mathrm{C}-7$ and C-8. Therefore, it can be formulate as 4-[(1E)-5-hydroxy-1-hexenyl]butan-4-olide (2, Figure 1).

This structure was supported by the ${ }^{1} \mathrm{H},{ }^{13} \mathrm{C}$ long-range correlations recorded for $\mathbf{2}$ in the HMBC spectrum (Table 1), ${ }^{13}$ and by data of its ESIMS spectrum, which showed the potassium $[\mathrm{M}+\mathrm{K}]^{+}$and the sodium $[\mathrm{M}+\mathrm{Na}]^{+}$cluster ions at $\mathrm{m} / \mathrm{z} 223$ and 207, respectively.

The stereochemistry of the double bonds of the side chain at C-4 of both $\mathbf{1}$ and $\mathbf{2}$ was deduced from the ${ }^{3} J_{\mathrm{H}, \mathrm{H}}$ coupling constants that are consistent for all with a transstereochemistry. $^{12}$ The stereochemistry of the secondary hydroxylated carbon at C-9 of diplofuranone A was determined applying the Mosher's method. ${ }^{16,17}$ Diplofuranone A by reaction with the $R$-(-)- $\alpha$-methoxy- $\alpha$-trifluorophenylacetate (MTPA) and $S$-(+)MTPA chlorides, was converted in the corresponding diastereomeric $S$-MTPA and $R$-MTPA esters (3 and 4, 
Figure 1), whose spectroscopic data were consistent with the structure assigned to 1 . The comparison between the ${ }^{1} \mathrm{H}-\mathrm{NMR}$ data (Table 2) of the $S$-MTPA ester (3) and those of the $R$ MTPA ester (4) of 1 [ $\delta S-\delta R:\left(\mathrm{H}-2^{\prime}\right)=-0.01 ;\left(\mathrm{H}-3^{\prime}\right)=-0.01 ;(\mathrm{H}-4)=-0.04 ;(\mathrm{H}-5)=-0.02 ;(\mathrm{H}-6)=-$ $0.01 ;(\mathrm{H}-8)=-0.01 ;(\mathrm{Me}-10)=+0.03]$ allowed to assign, in agreement to the Mosher's method ${ }^{17}$ and its further improvement, ${ }^{18}$ a $R$ configuration at C-9 of the side chain of $\mathbf{1}$. Diplofuranone A can be formulated as 4-[(5R,1E,3E)-5-hydroxyhexadienyl]-3,4-dihydro-2H-furanone (1, Figure 1).

Table 2. ${ }^{1} \mathrm{H}-\mathrm{NMR}$ data of the $(S)$ - and $(R)$ - $\alpha$-methoxy- $\alpha$-trifluorophenylacetate (MTPA) esters of diplofuranone A and B (3 and 4, respectively). Chemical shifts reported as $\delta$ from TMS

\begin{tabular}{ccc}
\hline & $\mathbf{3}$ & $\mathbf{4}$ \\
\hline Position & $\mathrm{H}$ & $\mathrm{H}$ \\
\hline 2 & $2.42 ; \mathrm{m}$ & $2.42 ; \mathrm{m}$ \\
& $2.00 ; \mathrm{m}$ & $2.01 ; \mathrm{m}$ \\
3 & $2.55 ; \mathrm{m}$ & $2.55 ; \mathrm{m}$ \\
& $2.00 ; \mathrm{m}$ & $2.01 ; \mathrm{m}$ \\
4 & $5.75 ; \mathrm{m}$ & $5.79 ; \mathrm{m}$ \\
5 & $5.63 ; \mathrm{dd}(14.7,6.4)$ & $5.65 ; \mathrm{dd}(15.1,7.3)$ \\
6 & $6.23 ; \mathrm{dd}(14.7,10.3)$ & $6.24 ; \mathrm{d}(15.1,10.3)$ \\
7 & $6.19 ; \mathrm{dd}(14.7,10.3)$ & $6.19 ; \mathrm{dd}(15.6,10.3)$ \\
8 & $5.67 ; \mathrm{dd}(14.2,6.8)$ & $5.68 ; \mathrm{dd}(15.6,6.8)$ \\
9 & $4.99 ; \mathrm{dq}(7.3,6.8)$ & $4.98 ; \mathrm{dq}(6.8,6.8)$ \\
$\mathrm{Me}$ & $1.32 ; \mathrm{d}(6.4)$ & $1.36 ; \mathrm{d}(6.4)$ \\
$\mathrm{OCH}_{3}$ & $3.57 ; \mathrm{s}$ & $3.54 ; \mathrm{s}$ \\
$\mathrm{Ph}$ & $7.60-7.26 ; \mathrm{m}$ & $7.60-7.26 ; \mathrm{m}$ \\
\hline
\end{tabular}

The absolute configuration of the two diplofuranones $\mathrm{A}$ and $\mathrm{B}$ could be assigned by the determination of the configuration of the stereogenic center $(\mathrm{C}-4)$ of the lactone ring applying the strategy of the $J$-based configurational analysis used for the related sapinofuranone $\mathrm{A}^{19}$ or method based on the exciton analysis of the circular dichroism spectrum and the ab initio calculation of the optical rotatory power used for diplopyrone. ${ }^{5}$ So, the results reported in this work allowed to restrict the possible stereoisomers, at least for $\mathbf{1}$, to two diastereomers.

Considering the structures of sapinofuranones it is also possible to hypothesize a biosynthetic pathway, which starting from this fungal metabolites, leads to diplofuranones $\mathrm{A}$ and $\mathrm{B}$ as reported in Figure 2. The first step could be the protonation of the hydroxyl group at C-5 of the side chain attached at $\mathrm{C}-4$ of the $\gamma$-lactone ring, followed by the elimination of a $\mathrm{H}_{2} \mathrm{O}$ molecule and the consequent shift of the double bond between $\mathrm{C}(6)-\mathrm{C}(7)$ to $\mathrm{C}(5)-\mathrm{C}(6)$ and that between $\mathrm{C}(8)-\mathrm{C}(9)$ to $\mathrm{C}(7)-\mathrm{C}(8)$ with the stereoselective attach of a $\mathrm{H}_{2} \mathrm{O}$ molecule at C-9. Finally, the deprotonation of the intermediate protonated alcohol generate the diplofuranone A (1). The 
successive reduction of the double bond between $\mathrm{C}(7)-\mathrm{C}(8)$ yielded the diplofuranone $\mathrm{B}(2)$. This hypothesized biosynthetic mechanism is in full agreement with the stereostructural features of (1) and (2) and allow to rule out the possibility that these two metabolites could be formed by sapinofuranones as an artefact of the work-up of the fungal culture filtrates. This biosynthetic mechanism was supported by the stereochemistry of C-9 and $\mathrm{C}(5)-\mathrm{C}(6)$ and $\mathrm{C}(7)-\mathrm{C}(8)$ double bonds, which have E-configuration in both (1) and consequently also in (2), and by the absence of other possible stereoisomers in the fungal culture filtrates.

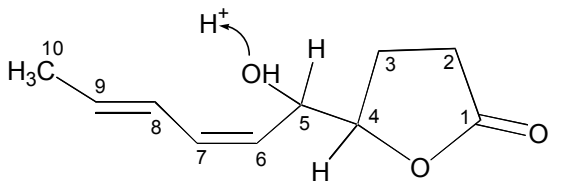

sapinofuranones

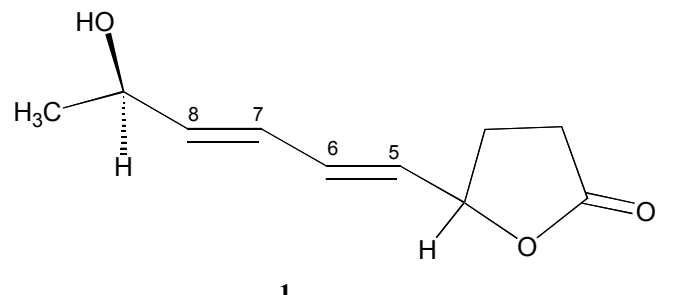

1

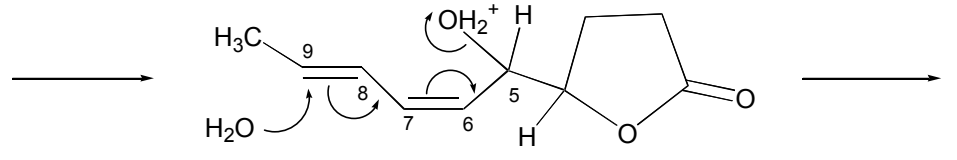

$\stackrel{\text { Reduction }}{\longrightarrow}$

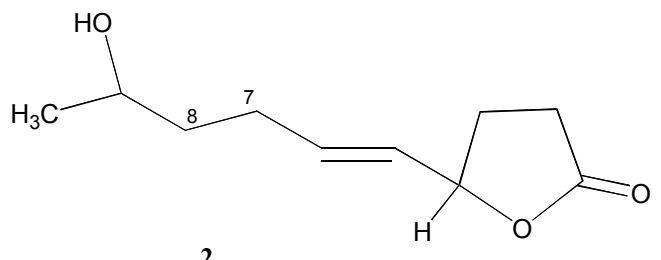

Figure 2. Biosynthetic pathway of sapinofuranones conversion into diplofuranones A and B (1 and 2)

Diplofuranones are strictly related to the sapinofuranones A and B isolated for the first time from Sphaeropsis sapinea infecting cypress tree ${ }^{7}$ and the $S, S$-enantiomer of sapinofuranone B which was previously isolated from Acremonium strictum, a saprophytic fungus commonly found in soil and plant surfaces. ${ }^{20}$ Butanolides are rare as naturally occurring compounds but are closely related to butenolides, which are well known as plant, fungal and lichen metabolites that also exhibit interesting biological activity. ${ }^{21}$ Among these there are the seiridins, which are 3,4dialkylbutenolides isolated from the culture filtrates of three species of Seiridium associated with the canker diseases of cypress. ${ }^{22,23}$

\section{Chemotaxonomic significance}

Independently from the phytotoxic activity, the occurrence of diplofuranones A (1) and B (2) may help to understand whether changes in the molecular structure of sapinofuranones affect its biological activity on host and non-host plants. ${ }^{7}$ Furthermore, understanding of the secondary metabolism of $D$. corticola could help to elucidate the taxonomic relationship between $D$. corticola and D. mutila, the fungus most frequently isolated from branches and twigs of 
declining oaks, ${ }^{24}$ S. sapinea f. sp. cupressi [syn: Diplodia pinea (Desm) Kickx, Petrax et Sydow f. sp. cupressi] and S. sapinea (Fr.:Fr.) Dyko \& Sutton an opportunistic pathogen of more than 30 species of Pinus in 25 countries. ${ }^{25}$ In fact, it is important to point out that D. corticola produces diplopyrone, diplofuranones, diplobifuranylones, sphaeropsidins A-C, sapinofuranones and 4-hydroxymelleins while D. mutila produces sphaeropsidins A and $\mathrm{C}^{26}{ }^{26}$. sapinea f. sp. cupressi produces sphaeropsidins A-F and sphaeropsidones ${ }^{3}$, while $S$. sapinea only produces sapinofuranones A and B. ${ }^{7}$ Therefore, D. corticola produces toxins in part similar to those (sphaeropsidins) produced by $D$. mutila and $S$. sapinea f. sp. cupressi, and those (sapinofuranones) of $S$. sapinea, but differ for the original biosynthesis of diplopyrone, the main phytotoxin, diplobifuranylones, diplofuranones, and the 4-hydroxymelleins.

\section{Experimental Section}

General Procedures. Optical rotation was measured in $\mathrm{CHCl}_{3}$ solution on a JASCO P-1010 digital polarimeter; IR and UV spectra were determined as neat and in $\mathrm{CH}_{3} \mathrm{CN}$ solution, respectively, on a Perkin-Elmer Spectrum ONE FT-IR spectrometer and a Perkin-Elmer Lambda $25 \mathrm{UV} /$ Vis spectrophotometer; ${ }^{1} \mathrm{H}$ - and ${ }^{13} \mathrm{C}-\mathrm{NMR}$ spectra were recorded at $400 \mathrm{MHz}$ and 100 $\mathrm{MHz}$, respectively, in $\mathrm{CDCl}_{3}$, on Bruker spectrometers. The same solvent was used as internal standard. Carbon multiplicities were determined by DEPT spectrum. ${ }^{13}$ DEPT, COSY-45, HSQC, HMBC experiments ${ }^{13}$ were performed using Bruker microprograms. HREIMS and EIMS were taken $70 \mathrm{eV}$ and on a Fisons Trio-2000 and a Fison ProSpec spectrometer, respectively. ESI MS were recorded on a Perkin-Elmer API 100 LC-MS; a probe voltage of $5300 \mathrm{~V}$ and a declustering potential of $50 \mathrm{~V}$ were used. Analytical and preparative TLC were performed on silica gel (Merck, Kieselgel 60, F254, 0.25 and $0.5 \mathrm{~mm}$ respectively), or on reversed-phase (Merck, RP$18, \mathrm{~F}_{254}, 0.25 \mathrm{~mm}$ ) plates. The spots were visualized by exposure to UV radiation and by spraying with $10 \% \mathrm{H}_{2} \mathrm{SO}_{4}$ in $\mathrm{MeOH}$ and then with $5 \%$ phosphomolybdic acid in $\mathrm{MeOH}$, followed by heating at $110{ }^{\circ} \mathrm{C}$ for $10 \mathrm{~min}$. Column chromatography was performed on silica gel (Merck, Kieselgel 60, 0.063-0.20 mm).

Fungal strain. The $D$. corticola strain, used in this study, was isolated from stems of infected cork oak (Q. suber) trees collected in Sardinia (Italy). A single spore isolate of $D$. corticola was grown on potato-dextrose-agar slants at $25^{\circ} \mathrm{C}$ for 10 days and then stored at $5{ }^{\circ} \mathrm{C}$ in the fungal collection of the "Dipartimento di Protezione delle Piante, Università di Sassari", Italy (PVS 114S).

Production, extraction and purification of diplofuranones A and B. The isolate PVS 114S of $D$. corticola was grown in stationary culture as previously reported ${ }^{6}$. The extraction of the culture filtrates (10 l) as well as the purification of the corresponding organic extract (960 mg) were carried out as previously reported ${ }^{6}$. This purification gave 11 groups of homogeneous fractions. The phytotoxic activity was concentrated in fractions 6-10. Successive purification of 
the fraction 6 residue $(90 \mathrm{mg})$, by silica gel column gave six combined fraction, of which only fractions 1, 4 and 5 showed phytotoxivc activity. The purification of the latter three fractions by combined column and TLC steps as previously detailed described, ${ }^{6}$ gave the phytotoxin sphaeropsidins $\mathrm{A},{ }^{27} \mathrm{~B}$ and $\mathrm{C},{ }^{3}$ sapinofuranone $\mathrm{B},{ }^{7}$ the $(3 S, 4 R)$-trans- and $(3 R, 4 R)$-cishydroxymellein, ${ }^{9-11}$ the diplobifuranylones $\mathrm{A}$ and $\mathrm{B}^{6}$ and the diplopyrone. ${ }^{4}$ The residue of fraction $5(59.6 \mathrm{mg}$ ) of the initial column purified by TLC steps (EtOAc- $n$-hexane, 1.5:1) yielded two metabolites as homogeneous oils resistant to crystallization, named diplofuranones A and B ( 1 and 2,10 and $1.8 \mathrm{mg}, 1$ and $0.2 \mathrm{mg} / 1$ ) $\left[R_{f} 0.37\right.$ and 0.36 and 0.46 and 0.14 , eluent systems $\mathrm{CHCl}_{3}-i-\mathrm{PrOH}$ (19:1), AcOEt- $n$-hexane (1.5:1), respectively].

Diplofuranone A (1). Colourless oil; $[\alpha]^{25}{ }_{D}+9.0^{\circ}$ (c 0.16); UV $\lambda_{\max } \mathrm{nm}(\log \varepsilon)$ : 230 (4.3); IR $v_{\max } \mathrm{cm}^{-1}: 3422,1770,1650,1182$; ${ }^{1} \mathrm{H}$ - and ${ }^{13} \mathrm{C}$-NMR: see Table 1; HREIMS (rel. int.) $\mathrm{m} / \mathrm{z}$ : $182.0854[\mathrm{M}]^{+}(6 \%)\left(\mathrm{C}_{10} \mathrm{H}_{14} \mathrm{O}_{3}\right.$ requires 182.0843), $167[\mathrm{M}-\mathrm{Me}]^{+}(15), 164\left[\mathrm{M}-\mathrm{H}_{2} \mathrm{O}\right]^{+}(28), 149$

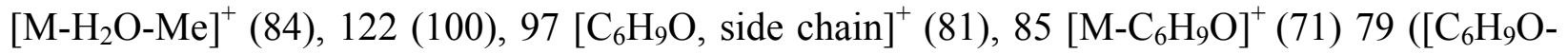
$\left.\mathrm{H}_{2} \mathrm{O}\right]^{+}(90)$; ESIMS (+), $m z: 221[\mathrm{M}+\mathrm{K}]^{+}, 205[\mathrm{M}+\mathrm{Na}]^{+}$.

Diplofuranone B (2). Colourless oil; [ $\alpha]^{25}{ }_{D}+32.8^{\circ}$ (c 0.11); UV $\lambda_{\max } n m(\log \varepsilon)$ : 225 (3.29); IR $v_{\max } \mathrm{cm}^{-1} 1$ : 3477, 1768, 1698; ${ }^{1} \mathrm{H}$ - and ${ }^{13} \mathrm{C}-\mathrm{NMR}$ : see Table 1; HREIMS (rel. int.) $\mathrm{m} / \mathrm{z}: 184.1109$ $[\mathrm{M}]^{+}(9 \%)\left(\mathrm{C}_{10} \mathrm{H}_{16} \mathrm{O}_{3} \text { requires 184.1099), } 169 \text { [M-Me] }\right]^{+},(12), 166\left[\mathrm{M}-\mathrm{H}_{2} \mathrm{O}\right]^{+},(24), 151\left[\mathrm{M}-\mathrm{H}_{2} \mathrm{O}-\right.$

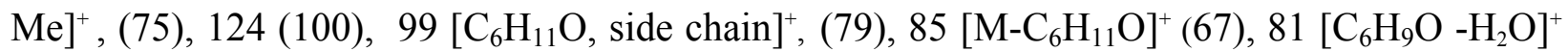
(88); ESIMS (+) (rel. int.) $m / z 207[\mathrm{M}+\mathrm{Na}]^{+}, 223[\mathrm{M}+\mathrm{K}]^{+}$.

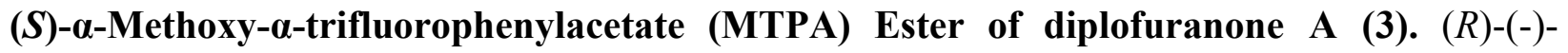
MPTA-Cl $(5 \mu \mathrm{l})$ was added to diplofuranone A $(1,1.5 \mathrm{mg})$, dissolved in dry pyridine $(20 \mu \mathrm{l})$. The mixture was allowed to stand at room temperature. After $2 \mathrm{~h}$, the reaction was complete, and $\mathrm{MeOH}$ was added. The pyridine was removed by a $\mathrm{N}_{2}$ stream. The residue was purified by preparative TLC on silica gel (petroleum ether- $\left.\mathrm{Me}_{2} \mathrm{CO}, 2.3: 1\right)$ yielding 3 as an oil (1.6 mg): $[\alpha]_{\mathrm{D}}^{25}-30.3^{\circ}$ (c 0.17); UV $\lambda_{\max } \mathrm{nm} \log (\varepsilon): 230$ (4.48); IR $v_{\max } \mathrm{cm}^{-1}: 1774,1746,1639,1452,1451$, 1268, 1168; 'H-NMR: see Table 2;. ESIMS (+), $m / z$ : $453[437]^{+}, 421[\mathrm{M}+\mathrm{Na}]^{+}, 399[\mathrm{MH}]^{+}$.

$(R)$ - $\alpha$-Methoxy- $\alpha$-trifluorophenylacetate (MTPA) Ester of diplofuranone A (4). (S)-(+)MPTA-Cl $(5 \mu \mathrm{l})$ was added to diplofuranone A $(1,1.5 \mathrm{mg})$, dissolved in dry pyridine $(20 \mu \mathrm{l})$. The reaction was carried out under the same conditions used for preparing 3 from $\mathbf{1}$. Purification of the crude residue by preparative TLC on silica gel (petroleum ether- $\mathrm{Me}_{2} \mathrm{CO}, 2.3: 1$ ) yielded 4 as an oil $(1.4 \mathrm{mg}):[\alpha]_{\mathrm{D}}^{25}+40.3^{\circ}(c 0.16)$; UV $\lambda_{\max } \mathrm{nm}(\log \varepsilon): 231(4.32) ; \mathrm{IR} v_{\max } \mathrm{cm}^{-1}: 1774$, 1746, 1452, 1269, 1169; ' $\mathrm{H}-\mathrm{NMR}$ : see Table 2; ESIMS (+), $m / z: 453[437]^{+}, 421[\mathrm{M}+\mathrm{Na}]^{+}$, $399[\mathrm{MH}]^{+}$.

Tomato cutting assay. Diplofuranones A (1) was assayed for phytotoxicity on non-host plant (tomato: Lycoperson esculentum L. var. Marmande) as previously described. ${ }^{6}$ The pure substance was dissolved in acetone and tested at concentrations of $0.05-0.2 \mathrm{mg} \mathrm{m} / 1$. 


\section{Acknowledgments}

This investigation was supported by grants from the Italian Ministry of University and Scientific Research (MIUR). The authors thank Dr. R. Ferracane (Dipartimento di Scienza degli Alimenti, Università Federico II, Napoli, Italy) for mass spectra and 'CIMCF, Centro Interdipartimentale di Metodologie Chimico-Fisiche, Università di Napoli Federico II”, Italy' for ESI MS and NMR spectra, respectively. Contribution DISSPA 124.

\section{References}

1. Franceschini, A.; Corda, P.; Maddau, L.; Marras, F. IOBC/wprs Bulletin 1999, 22, 5.

2. Franceschini, A.; Maddau, L.; Marras, F. IOBC/wprs Bulletin 2002, 25, 29.

3. Evidente, A.; Sparapano, L.; Fierro, O.; Bruno, G.; Giordano, F.; Motta, A. Phytochemistry 1997, 45, 705.

4. Evidente, A.; Maddau, L.; Spanu, E.; Franceschini, A.; Lazzaroni, S.; Motta, A. J. Nat. Prod. 2003, 66, 313.

5. Giorgio, E.; Maddau, L.; Spanu, E.; Evidente, A.; Rosini, C. J. Org. Chem. 2005, 70, 7.

6. Evidente, A.; Andolfi, A.; Fiore, M.; Spanu, E.; Maddau, L.; Franceschini, A.; Marras, F.; Motta, A. J. Nat. Prod. 2006, 69, 671.

7. Evidente, A.; Sparapano, L.; Fierro, O.; Bruno, G.; Motta, A. J. Nat. Prod. 1999, 62, 253.

8. Aldridge, D.C.; Galt, S.; Giles, D.; Turner, W. B. J. Chem. Soc. (C) 1971, 1623.

9. Cole, J. C.; Cox, R. H. Handbook of Toxic Metabolites; Academic Press: New York, 1981, pp 129-151.

10. Devis, M.; Barbier, M. Z. Naturforsch. 1992, 47c, 779.

11. Nakanishi, K.; Solomon, P. H. Infrared Absorption Spectroscopy, Holden-Day Inc.: Oakland, CA, 1977; pp 17-44.

12. Pretsch, E.; Bühlman, E.; Affolter, C. Structure Determination of Organic Compound Tables of Spectral Datas, Springer: Berlin, 2000; pp 161-243, 385-404.

13. Berger, S.; Braun, S. 200 and More Basic NMR Experiments: a Practical Course, WileyVCH: Weinheim, 2004.

14. Breitmaier, E.; Voelter, W. Carbon-13 NMR Spectroscopy, VCH: Weinheim, 1987, pp 183280.

15. Porter, Q. N. Mass Spectrometry of Heterocyclic Compounds, John Wiley \& Sons: New York, 1985, pp 55-58, 262-266.

16. Dale, J. A.; Dull, D. L.; Mosher, H. S. J. Org. Chem. 1969, 34, 2543.

17. Dale, J. A.; Mosher, H. S. J. Am. Chem. Soc. 1973, 95, 512.

18. Ohtani, I.; Kusumi, T.; Kashman, Y.; Kakisawa H. J. Am. Chem. Soc. 1991, 113, 4092.

19. Cimmino, P.; Bifulco, G.; Evidente, A.; Abouzeid, M. A.; Riccio, R.; Gomez-Paloma, L. Org. Letters 2002, 4, 2779. 
20. Clough, S.; Raggatt, M. E.; Simpson, T. J.; Wilis, L. C.; Whiting, A.; Wrigley, S. K. J. Chem. Soc., Perkin Trans. I 2000, 2475.

21. Dean, F. M.; Naturally Occurring Compounds, Butterworth: London, 1963, pp 53-81

22. Sparapano, L.; Evidente, A.; Ballio, A.; Graniti, A.; Randazzo, G. Experientia 1986, 42, 627.

23. Evidente, A.; Sparapano, L. J. Nat. Prod. 1994, 57, 1720.

24. Kolwaski, T. Eur. J. Foren. Pathol. 1991, 21, 136.

25. Swart, W. J.; Wingfield, M. J. Plant Dis. 1991, 75, 761.

26. Sparapano, L.; Bruno, G.; Fierro, O.; Evidente, A. Phytochemistry 2004, 65, 189.

27. Evidente, A.; Sparapano, L.; Motta, A.; Giordano, F.; Fierro, O.; Frisullo, O. Phytochemistry 1996, 42, 1541. 